\title{
Web-Based New Student Admission Information System Using Waterfall Method
}

\author{
Febri Aldi \\ Universitas Putra Indonesia "YPTK", Padang, Indonesia \\ febri_aldi@upiyptk.ac.id
}

Submitted : Jan 1, 2022 | Accepted : Jan 5, 2022 | Published : Jan 7, 2022

\begin{abstract}
The current development of information technology on the activities of people's daily lives is very influential. Where in doing an activity that takes a lot of time can be shortened to complete it. One of the things that we can see at this time is in the field of education. Education service technology is feasible if the government, education service providers, and the community all work together. The problem is how to build information system technology that can provide educational service processes without intervening in existing operational standards. The New Student Admissions Information System is a website-based platform designed to enable public access to information about schools and the new student registration process. The waterfall approach was used to construct this information system, together with the PHP programming language, the Codeigniter 3 framework, the MVC pattern, and the MySQL database. The results obtained in the form of a new student admission information system website that provides services related to registration, and processing of registration data by the school administration. With this research, it is expected to facilitate new student admission officers at Al Azhar Islamic Elementary School 32 Padang to process data well, and help parents to register their children as new students at Al Azhar Islamic Elementary School 32 Padang.
\end{abstract}

Keywords: PMB; Waterfall; Codeigniter 3; MySQL; Website; MVC

\section{INTRODUCTION}

The Internet is one of the scientific and technological advancements that have successfully connected millions of people worldwide and facilitated the quick distribution of information. The use of the internet in the world of education has a big role in advancing education itself. One of them is applied in the admission of new students in elementary schools. Because this new student admission activity is one of the first steps to start the education process in a school. In new student admission activities, the school must have a strategy so that prospective new students are interested in enrolling in the school. Of course, the interest arises because of the information obtained by prospective new students about the school.

In addition to information that is easily obtained by prospective new students, the most important thing is the ease in the registration process. Moreover, because of the covid-19 pandemic, parents do not want to come directly to school because they are exposed to covid-19. Then prospective new students must prepare hard documents as a registration requirement, so that there is a buildup of documents in school. Registration data needs to be manually designed through the Microsoft excel application. Feared the occurrence of errors in data input, data is not stored securely, and loss of registration data.

So this is behind the creation of a new student admission information system based on the website as an ease offered to schools so that new student admission activities can run efficiently and effectively. And provide convenience to the community to get information about the school and ease in the application process at the school. As well as the convenience that schools use in storing registration data, creating reports, and storing data safely. The waterfall method is used to develop this information system. The waterfall technique is a process that emphasizes the importance of developing a model sequentially and structuredly in order to ensure that its execution is adequately documented and cost effective. In comparison to agile methodologies, which are typically more expensive as a result of user feedback regarding software product updates or additions (Utami, Zen, \& Rauna, 2021). Additionally, the Waterfall method is well-suited for large-scale software development projects that require a significant number of sophisticated resources and working procedures. Additionally, this platform is developed using the CodeIgniter 3 framework. Whereas CodeIgniter 3 is a PHP framework that utilizes the MVC pattern to

*Corresponding Author 
facilitate maintenance. Additionally, this framework implements an OOP notion, which simplifies problem solving for developers, eliminates the need to create code again, and makes it customizable..

\section{LITERATURE REVIEW}

Today, as technology advances and enters the realm of education, its usage becomes increasingly ubiquitous. One of them is internet use. Known as the Internet, it is a worldwide computer network made up of various local and regional networks that allows data to be exchanged between computers that are connected to it. (Tabrani \& Pudjiarti, 2017). The website is one of the applications of internet technology. A website is a group of pages that display some data: text, static, images or motion, animation, sound, and video, or a combination of all of them, both static and dynamic, which form a collection of interconnected structures that are linked together via a web of pages. (hyperlinks) (Wijaya \& Christian, 2019).

PHP is a programming language that is commonly used to create websites. PHP began as a small opensource project that gained in popularity as more people discovered its utility. PHP was created by Rasmus Lerdorf in 1994. PHP is an abbreviation for "PHP: Hypertext Preprocessor", which is a recursive acronym for "PHP: Hypertext Preprocessor". PHP is an HTML-based server-side scripting language. Used to manage dynamic content, databases, and session tracking, as well as to construct whole e-commerce websites. PHP is compatible with a number of well-known databases, including MySQL, PostgreSQL, Oracle, Sybase, Informix, and Microsoft SQL Server (Ogala, 2019). When developing website applications, a framework is utilized to provide the basic structure for the computer code. A framework is a logical structure for a program which enables programmers to construct applications more easily, adapt them, and reuse them for other applications that are related (Suharsana, Wirawan, \& S, 2016).

CodeIgniter is a web application framework. CodeIgniter is an open-source platform that enables users to construct dynamic PHP programming languages quickly and easily. The benefit and aim of constructing an application with CodeIgniter is to assist developers in creating applications more quickly than they could by writing all the source code from start, and CodeIgniter includes a variety of libraries that enable building and developing apps easier. On 2006, CodeIgniter was made generally available to the public. CodeIgniter was established and developed in accordance with the Model-View-Controller (MVC) paradigm (Endra, Cucus, \& Wulandana S, 2020). Model-View-Controller (MVC) is a notion established by Smalltalk's founder (Trygve Reenskaug) to summarize data together with its processing (model), isolate it from the manipulation process (controller), and show it on the user interface (view) (Sudrajat, Irianingsih, \& Krisnawan, 2017).

A database is a set of data that is organized and managed in a systematic fashion on a computer and may be analyzed or altered to generate information using software (application programs). Database definitions specify the data types, structures, and constraints on the data that will be stored (Tristianto, 2018). Oracle Corporation created, distributed, and supported MySQL, a widely used open-source SQL database management system. MySQL is a relational database management system (RDBMS) that is used to manage structured data MySQL databases enable you to create, access, and process database-stored data. Separate tables are used by MySQL to hold data. The database structure is divided into fast-loading physical files. Logical models, with their associated objects like as databases, tables, views, rows, and columns, provide a highly versatile programming environment. The SQL in "MySQL" refers to "Structured Query Language," the most widely used standard language for database access. MySQL is an opensource database management system that is licensed under the GPL (GNU General Public License) (Arne, 2019).

B.W. Boehm's waterfall model is a sequential design method that is commonly employed in traditional software development. This model depicts progress as it cascades down through all phases, including conception, initiation, analysis, design, building, testing, production/implementation, and maintenance. The building and industrial industries inspired the notion for this model. This model depicts an extremely structured physical environment that is impenetrable. Due to the absence of a formal software development methodology in the past, and the fact that hardware-centric architecture was adapted solely for the purpose of software development. (Manhas, 2017). The Waterfall technique is a sequential software development strategy that views proceed as a continuous downward flow (like in waterfalls) through the phases of design, modeling, implementation (construction), and testing.. The waterfall approach includes the following steps throughout its development: requirements (requirements analysis), system design, coding and testing, program implementation, and maintenance (Tristianto, 2018).

The test technique (or strategy) dictates how a test case should be designed. They might be functional or nonfunctional. They can be based on responsibility (black box), implementation (white box), or both. Black Box Testing is used to identify a variety of issues, including malfunctions, interface errors, data structure errors, malfunctions, declaration and termination mistakes, and malfunctions (Mustaqbal, Firdaus, \& Rahmadi, 2015). Black-box testing is a form of software testing that focuses exclusively on the software's functional specifications.

*Corresponding Author 
Testing operates by oblivious to the control framework in favor of domain knowledge. A system's functional restrictions can be fully exploited through black-box testing. (Kartiko, 2020).

\section{METHOD}

Waterfall Software Development is used to create the website. The Waterfall Software Development Method consists of six stages: analysis of requirements, design of the system, implementation, testing, and implementation.

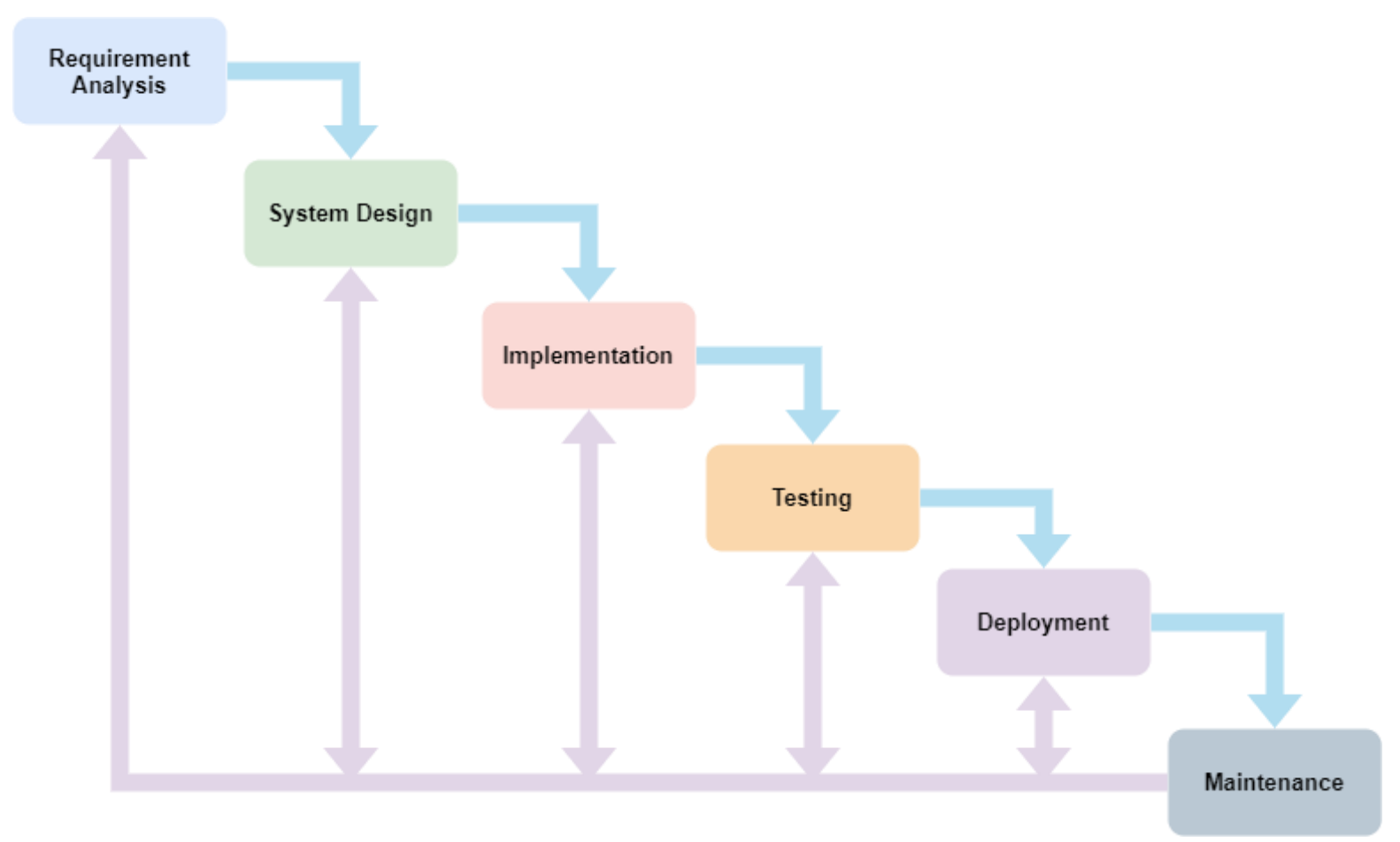

Fig. 1 Software Development Models

\section{Needs Analysis}

This is the stage during which the developer prepares and examines the requirements for the next software. Observation and interviewing are used to ascertain excavation requirements, and the following results are obtained:

Table 1

Requirement Stage

Stage Needs

$\begin{array}{ll}\text { Observation } & \text { Conduct observations of numerous existing websites } \\ \text { in order to amass sufficient knowledge for } & \text { construction. } \\ \text { Interview } & \text { In this instance, an interview with the administrative } \\ \text { department is done with the following question: how } & \text { is the service in the acceptance of new students? What } \\ \text { is the SOP of a new student admissions service if it is } & \text { done digitally, flexibly or poses new problems? What } \\ \text { is the efficiency and effectiveness if the new student } \\ \text { admissions service is done digitally? Is it expected that } \\ \text { this new method will help for new students to receive } \\ \text { services? }\end{array}$




\section{System Design}

Use Case Diagram

The term "Use Case" refers to the interaction between one or more actors and the system that is being developed (Heriyanti \& Ishak, 2020). More specifically, use case diagrams have been used to represent the functions contained within a system as well as the individuals who have access to those functions (Hendini, 2016).

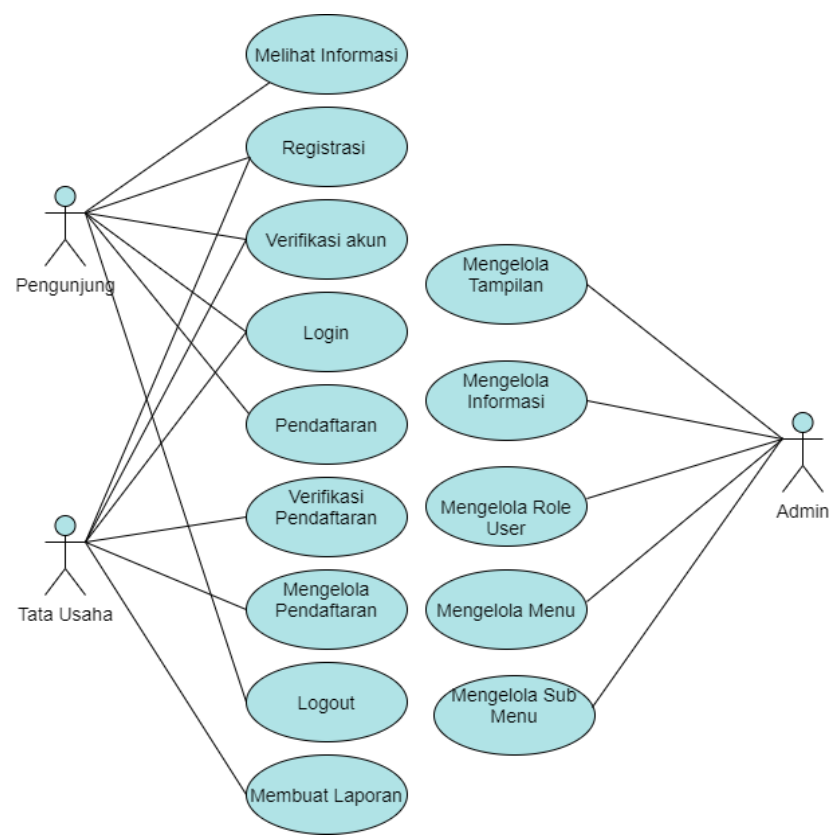

Fig. 2 Use Case Diagram

ER Diagram

The ER diagram is a data structure that is used to represent the relationships between data in a database. It is constructed using data objects that have relationships between them (Fridayanthie \& Mahdiati, 2016).

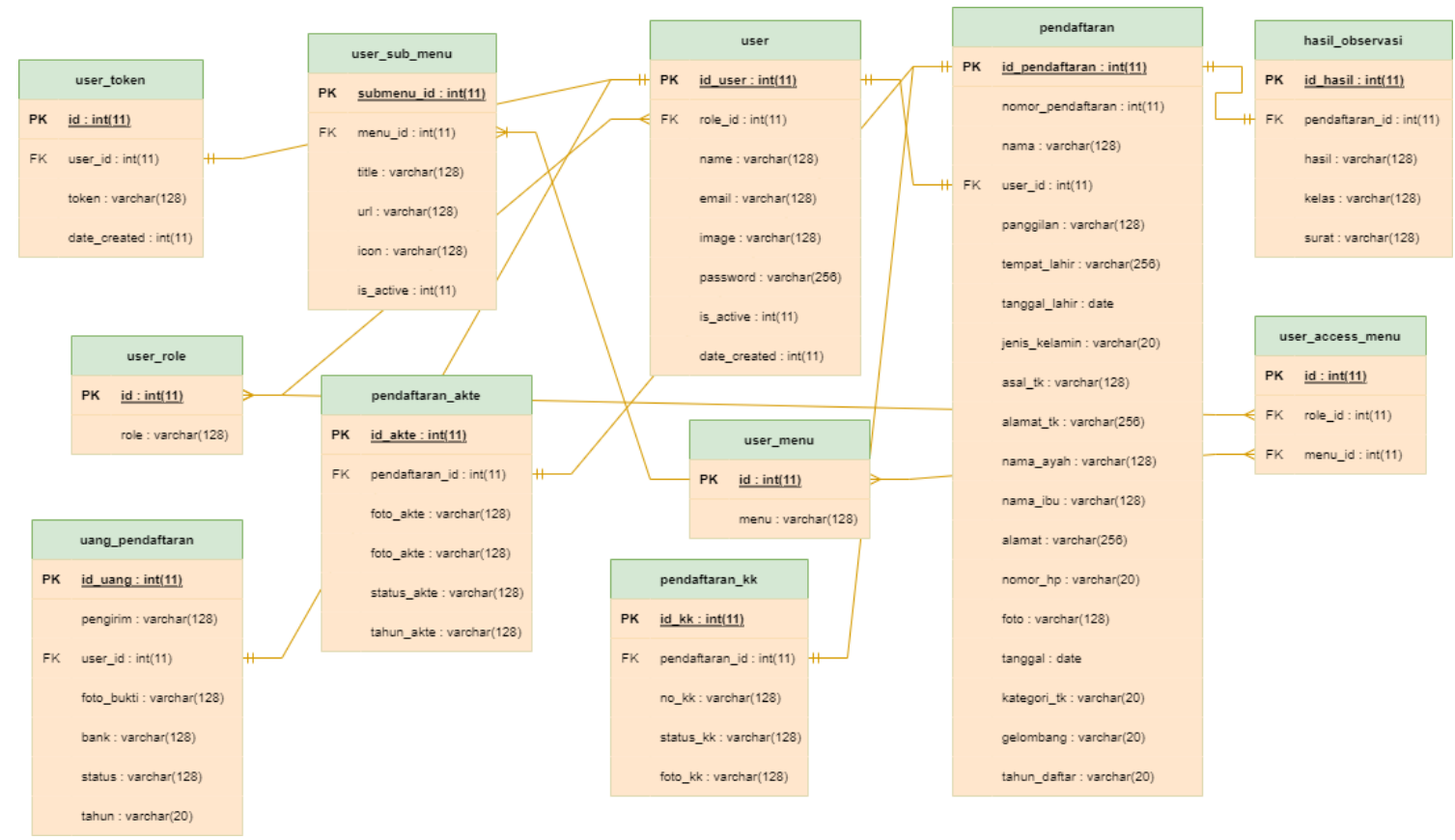

Fig. 3 ER Diagram

*Corresponding Author 


\section{Implementation}

Coding implementation is the process of converting schematics to source code and converting it into a usable website. The author of this website makes extensive use of the CodeIgniter 3 framework. Authors write code using Microsoft Visual Studio coding applications. Model, View, and Controller are the three major sections of the code file. A model is a folder or directory that includes database-specific code. The model section contains all databaserelated functions such as creating, reading, updating, and deleting. A view folder includes the code necessary to render a website to a user. The view folder is used to identify the frontend. A controller folder contains the code necessary to connect the model's function to the view section.

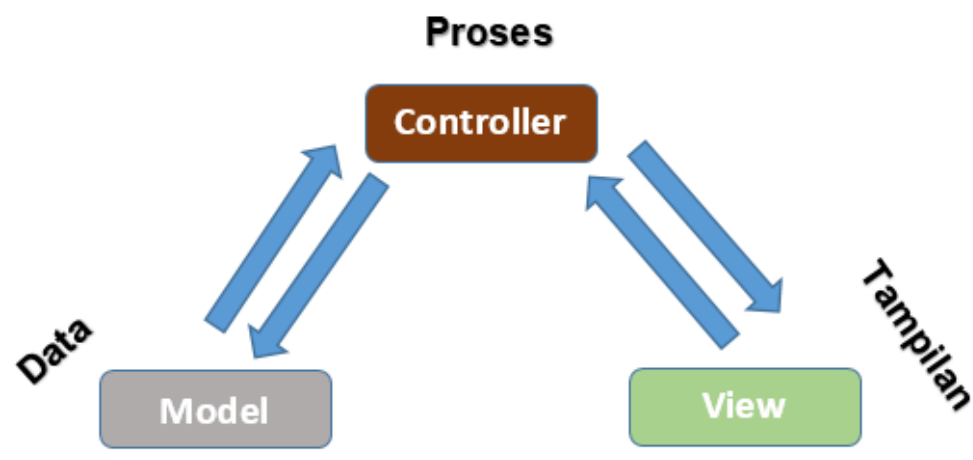

Fig. 4 Model View Controller

\section{Testing}

The initial stage of testing is to validate the program's overall functionality. The researchers conducted the experiment with three accounts: a repeater account, a business administration account, and an administrator account. The black box testing technique is utilized in the testing system. The researchers validated visitors' functioning by registering, logging in, filling out biodata, uploading files and printing proof of registration. On the administrative side, researchers conduct testing by testing the function of business, where the business can login, view registration data, validate registration data, and also print reports. While from the admin side researchers tested it by trying to do CRUD on all tables displayed on the dashboard.

\section{Deployment}

Deployment is a process that enables developers to make apps available online. Following completion of the testing phase, the deployment process begins.

\section{Maintenance}

The final stage of system development is operations and maintenance. Based on these findings, determine whether this application requires enhancements such as error correction, repair, and the introduction of unit and service systems.

\section{RESULT}

This research has resulted in a new student admissions website called PMB SDIA 32 Padang. This website is a website that provides information about the admission of new students and the process of registering new students. This PMB website is divided into two main parts, namely: front end and back end. The front end consists of a landing page that contains our home menu, registration flow, information, and contacts. Then the back end consists of a section for the visitor dashboard, admin dashboard, and business dashboard. On the main page for visitors, activities that can be done include seeing information, registration, login, registering, printing proof of registration and joining whatsapp groups. Admin dashboard, admin can perform several activities that set user access rights through management menu and management sub menu, see the registration list. Additionally, administrators have the ability to create, delete, and change database data via the admin dashboard. You may see registration lists, validate and print data from the business dashboard, as well as add new data, delete and change registration-related data. 
On the home page there is a header containing the registration flow, information, contacts, and logins.

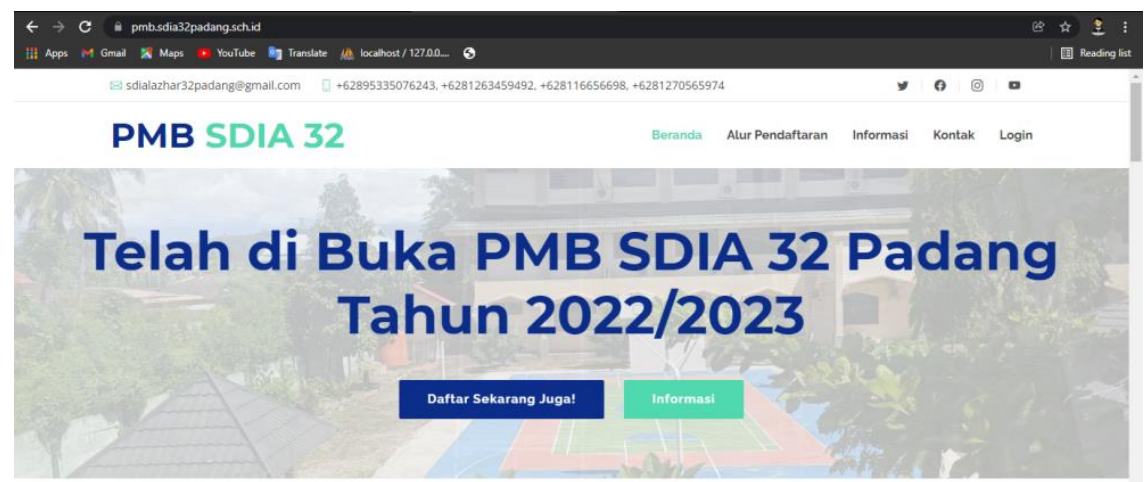

Fig. 5 Website Header

Visitors register on the PMB Registration page using an active email.

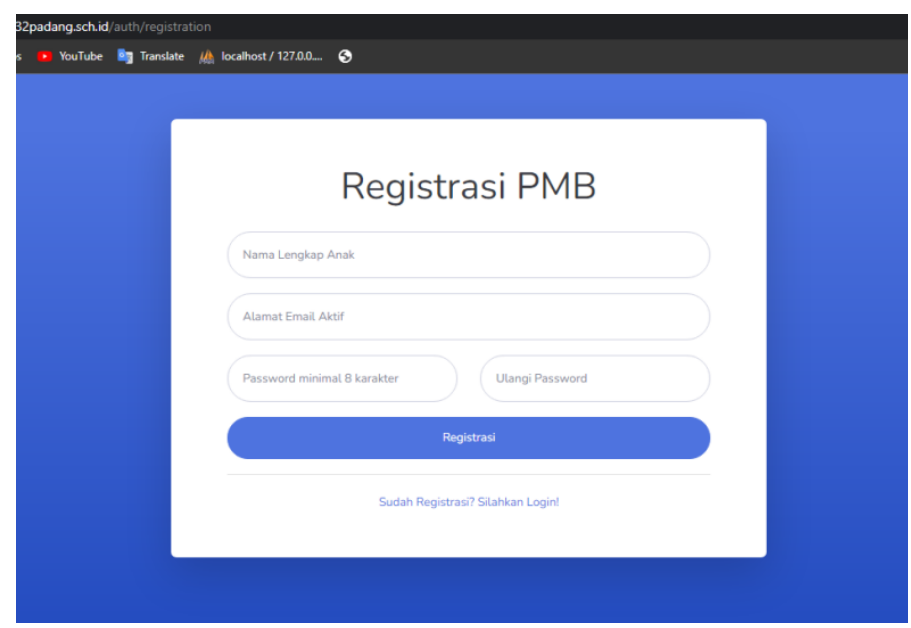

Fig. 6 Registration page

On the dashboard visitors can change the profile and change the password. Then do the registration process that begins by filling out the biodata and uploading the files. Furthermore, visitors can print proof of registration that will be brought at the time of observation. And can also join the whatsapp group through the button that has been provided, to get information from the next registration process.

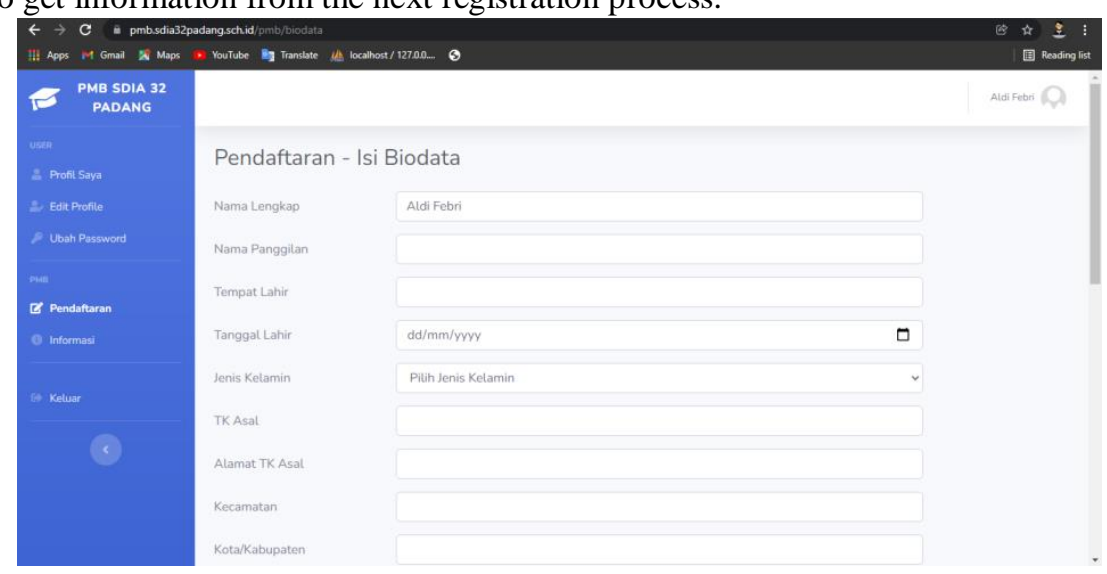

Fig. 6 Visitors Dashboard

*Corresponding Author 
There are four menu options available on the admin page: admin, user, menu, and verification. Admins can do CRUD (create, read, update, and delete) all the data in the admin dashboard.

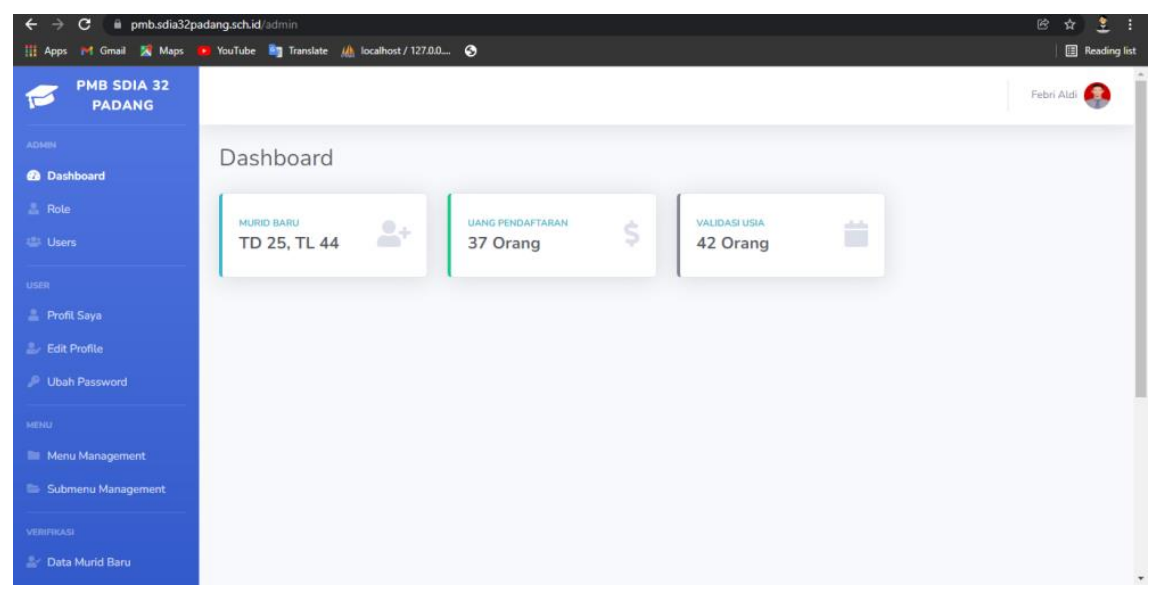

Fig. 7 Admin Dashboard

On the business administration page, the business entity can see the registration data that has been entered. In addition, the business administration validates the incoming registration data whether it meets the criteria that have been determined.

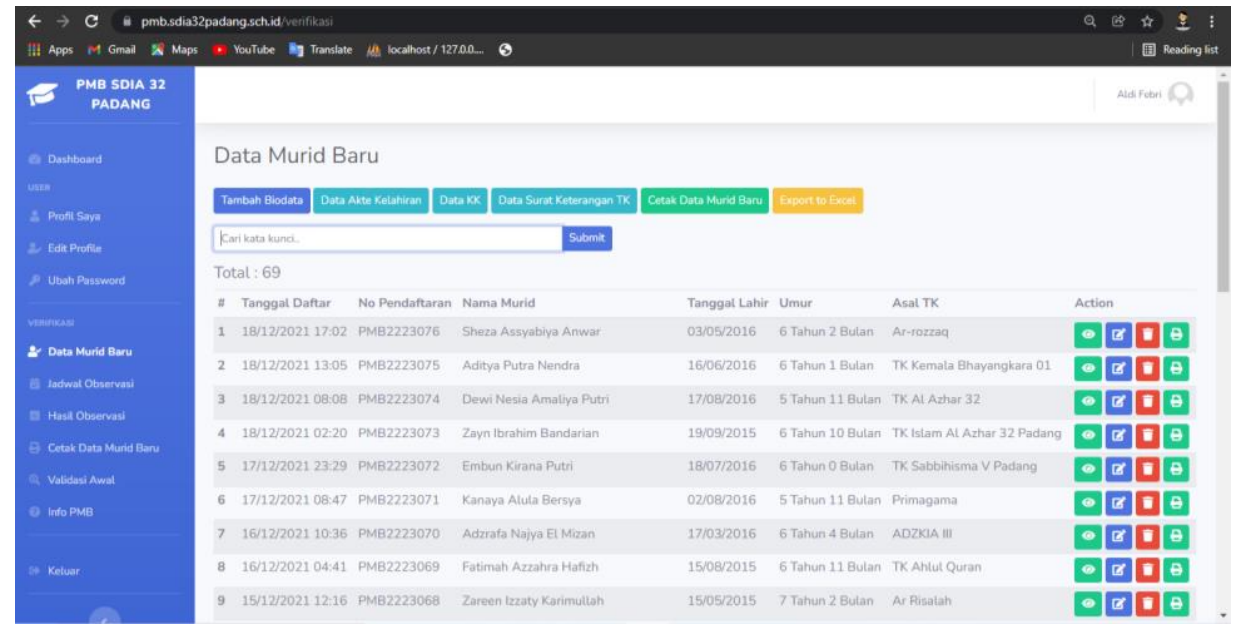

Fig. 8 Administration Dashboard

Following the completion of all website services development, the following stage is to conduct testing. The black box testing approach is employed during the testing procedure. Here are the results of the testing process written below:

Table 2

Black box method testing results

\begin{tabular}{lll}
\hline Name of Function & Activities & Result \\
\hline Website Header & Displays the website header & Success \\
Registration Page & Registration to create a registration account & Success \\
Biodata content page & Enter the full biodata of prospective registrants & Success \\
File Upload page & Upload registration files & Success \\
Admin Dashboard & View all existing tables & Success \\
Administration Dashboard & View incoming and validation registration data & Success \\
\hline
\end{tabular}




\section{DISCUSSIONS}

Al Azhar 32 Padang Islamic Elementary School's new student admissions website has an online-based new student registration service and provides information about schools and new student admissions. This website has 2 main parts, namely the front end and back end. The section to get information about the admission of new students is at the front end. Applicants can view information about requirements, fees, new student admission schedules, observation schedules and re-listing schedules. Registrants can also see the registration flow that can later be done in the back end. On the home section the registrant can start the registration process by clicking the Register Now Button, then the registrant is directed to the registration page on the back end of the website.

First visitors register an account on the PMB Registration page. At the time of registration enter the child's full name data, active parent email, and password. After that a notification will go to the registered email to activate the registration account. So that visitors can login and do the registration process. Next, visitors log in and register. Starting from uploading proof of registration, contents of biodata, upload files such as birth certificates and family cards. The final stage of the visitor checks whether the data is correct. If it is correct, continue registration. The results of the registration can print proof of registration and join the whatsapp group with the link that has been provided.

In the business section check the registration data that has been entered and validate whether the data is correct and in accordance with the uploaded files. After that the administration makes an observation schedule for each registrant. Which observation schedule can be seen by the registrant in the information page section. And on the information page, the registrant can also see the results of observations when the observation has been completed and inputted by the business administration. In the dashboard section admin can see, change roles, delete user data, and change the access menu of each user. And admins can also add, change, and remove menus and submenu needed by the school.

\section{CONCLUSION}

As a result of the evaluation and discussion that have been provided, the conclusion that can be taken is the PMB SDIA 32 Padang website is a website that provides new student registration services. This website provides information about the schools needed by the community. This new student admissions website provides time efficiency either in terms of registration in getting information and registration, or for schools that can know the public who want to enroll their children in Al Azhar Islamic Elementary School 32 Padang. The use of the codeigniter 3 framework results in a nice and structured file structure and code. It has been demonstrated via the black box testing method that all of the website's functionality are operational.

\section{REFERENCES}

Arne, P. H. (2019). Open Source Evolution v. 2019. Morris, Manning \& Martin, LLP. Retrieved from https://www.gnu.org/licenses/gpl-faq.html.

Endra, R. Y., Cucus, A., \& Wulandana S, M. A. (2020). Perancangan Aplikasi Berbasis Web Pada System Aeroponik untuk Monitoring Nutrisi Menggunakan Framework CodeIgniter. Explore: Jurnal Sistem Informasi Dan Telematika, 11(1), 10. https://doi.org/10.36448/jsit.v11i1.1453

Fridayanthie, E. W., \& Mahdiati, T. (2016). RANCANG BANGUN SISTEM INFORMASI PERMINTAAN ATK BERBASIS INTRANET (STUDI KASUS: KEJAKSAAN NEGERI RANGKASBITUNG). JURNAL KHATULISTIWA INFORMATIKA, IV(2), 126-138. Retrieved from http://www.bssaonline.org/content/95/6/2373\%5Cnhttp://www.bssaonline.org/content/95/6/2373.short\%0 Ahttp://www.bssaonline.org/cgi/doi/10.1785/0120110286\%0Ahttp://gji.oxfordjournals.org/cgi/doi/10.109 3/gji/ggv142\%0Ahttp://link.springer.com/10.1007/s00024-01

Hendini, A. (2016). PEMODELAN UML SISTEM INFORMASI MONITORING PENJUALAN DAN STOK BARANG (STUDI KASUS: DISTRO ZHEZHA PONTIANAK). JURNAL KHATULISTIWA INFORMATIKA, IV(2), 107-116. https://doi.org/10.1145/358315.358387

Heriyanti, F., \& Ishak, A. (2020). Design of logistics information system in the finished product warehouse with the waterfall method: review literature. IOP Conference Series: Materials Science and Engineering, 801(1), 012100. https://doi.org/10.1088/1757-899X/801/1/012100

Kartiko, C. (2020). Black Box Testing Boundary Value Analysis Pada Aplikasi Submission System. Edik Informatika, 6(2), 15-22. https://doi.org/10.22202/ei.2020.v6i2.3995

Manhas, J. (2017). Initial framework for website design and development. International Journal of Information Technology (Singapore), 9(4), 363-375. https://doi.org/10.1007/s41870-017-0045-4

Mustaqbal, M. S., Firdaus, R. F., \& Rahmadi, H. (2015). PENGUJIAN APLIKASI MENGGUNAKAN BLACK BOX TESTING BOUNDARY VALUE ANALYSIS (Studi Kasus : Aplikasi Prediksi Kelulusan SNMPTN). I(3), 3136.

*Corresponding Author 
Ogala, E. (2019). Concept of Web Programming, an Overview of Php Vol. 1. An Overview of PHP, l(April). Retrieved from https://www.researchgate.net/publication/341151029

Sudrajat, R., Irianingsih, I., \& Krisnawan, D. (2017). Analysis of data mining classification by comparison of C4.5 and ID algorithms Related content. IOP Conf. Series: Materials Science and Engineering, 166(012031). https://doi.org/10.1088/1757-899X/166/1/012031

Suharsana, I. K., Wirawan, I. W. W., \& S, N. L. A. K. Y. (2016). Implementasi Model View Controller Dengan Framework Codeigniter Pada E-Commerce Penjualan Kerajinan Bali. Jurnal Sistem Dan Informatika, 11(1), 19-28. Retrieved from https://media.neliti.com/media/publications/130604-ID-implementasi-model-viewcontroller-denga.pdf

Tabrani, M., \& Pudjiarti, E. (2017). PENERAPAN METODE WATERFALL PADA SISTEM INFORMASI INVENTORI PT. PANGAN SEHAT SEJAHTERA. Jurnal Administrasi Bisnis S1 Universitas Brawijaya, $1(2), 30-40$.

Tristianto, C. (2018). PENGGUNAAN METODE WATERFALL UNTUK PENGEMBANGAN SISTEM MONITORING DAN EVALUASI PEMBANGUNAN PEDESAAN. ESIT, 12(1), 8-22.

Utami, M., Zen, B. P., \& Rauna, Y. S. (2021). Developing a legal assistant website "Notoaturan" using Waterfall method. SinkrOn, 5(2), 229-238. https://doi.org/10.33395/sinkron.v5i2.10902

Wijaya, K., \& Christian, A. (2019). Implementasi Metode Model View Controller (MVC) Dalam Rancang Bangun Website SMK Yayasan Bakti Prabumulih. Paradigma - Jurnal Komputer Dan Informatika, 21(1), 95-102. https://doi.org/10.31294/p.v21i1.5092 